\title{
PENSION BUYOUTS: WHAT CAN WE LEARN FROM THE UK EXPERIENCE?
}

Ashby H. B. Monk*

CRR WP 2009-19

Released: September 2009

Draft Submitted: September 2009

Center for Retirement Research at Boston College

Hovey House

140 Commonwealth Avenue

Chestnut Hill, MA 02467

Tel: 617-552-1762 Fax: 617-552-0191

http://www.bc.edu/crr

* Ashby H. B. Monk is a Research Fellow at the Center for Retirement Research at Boston College (CRR) and a Research Fellow at the Oxford University Centre for the Environment. The research reported herein was performed pursuant to a grant from the U.S. Social Security Administration funded as part of the Retirement Research Consortium. The opinions and conclusions expressed are solely those of the author and do not represent the opinions or policy of the U.S. Social Security Administration, any agency of the Federal Government, or the Center for Retirement Research at Boston College. The author would like to thank David Blake, Gordon L. Clark, Adam Dixon, Andrew Eschtruth, Courtney Monk, Alicia Munnell, Michael Orszag, and four anonymized interviewees for helpful comments on a previous draft. None of the above are responsible for any errors or omissions contained herein.

(C) 2009, by Ashby H. B. Monk. All rights reserved. Short sections of text, not to exceed two paragraphs, may be quoted without explicit permission provided that full credit is given to the source. 


\title{
About the Center for Retirement Research
}

The Center for Retirement Research at Boston College, part of a consortium that includes parallel centers at the University of Michigan and the National Bureau of Economic Research, was established in 1998 through a grant from the Social Security Administration. The Center's mission is to produce first-class research and forge a strong link between the academic community and decision makers in the public and private sectors around an issue of critical importance to the nation's future. To achieve this mission, the Center sponsors a wide variety of research projects, transmits new findings to a broad audience, trains new scholars, and broadens access to valuable data sources.

\author{
Center for Retirement Research at Boston College \\ Hovey House \\ 140 Commonwealth Avenue \\ Chestnut Hill, MA 02467 \\ phone: 617-552-1762 fax: 617-552-0191 \\ e-mail: crr@bc.edu \\ www.bc.edu/crr
}

\author{
Affiliated Institutions: \\ The Brookings Institution \\ Massachusetts Institute of Technology \\ Syracuse University \\ Urban Institute
}




\begin{abstract}
Managing (or at least slowing) the decline of private defined benefit (DB) pensions has been a top priority for US policymakers. Any market-related developments or regulatory changes that alter the provision or sustainability of private DB pensions in other countries are thus relevant to policy and worth understanding. One such development taking place in the United Kingdom, pension fund buyouts, has enjoyed measured success.
\end{abstract}

A DB pension bulk buyout refers to a transaction in which a pension plan sponsor pays another company a fee to take over the assets and liabilities of the pension plan. Clearly such transactions are relevant to the provision and long-term sustainability of this institution. So, while the increasing popularity of these transactions is restricted to the UK, the market has garnered the attention of US financial services firms, plan sponsors and policymakers. This paper thus analyzes the growing market for DB pension buyouts in the UK and considers its implications for the US. It contributes to our understanding of the future prospects for employersponsored defined benefit pensions, and how they will contribute to retirement income over time.

Using various qualitative methodologies, this paper traces the evolution of the buyout from a transaction for insolvent plan sponsors to a transaction for solvent plan sponsors with funded pensions. While certain types of solvent buyouts have fallen out of favor, such as non-insured buyouts, the paper concludes that buyouts of the insured variety have a bright future. The increasingly burdensome nature of the DB pension plan will sustain this market over the long-term. 


\section{Introduction}

Over the past half century, employer-sponsored defined benefit (DB) pensions have been crucial sources of retirement income and security (see Sass, 2006). However, the popularity of DB pensions in the private sector is now on the decline (Clark and Monk, 2007). Only 30,000 US companies sponsored a DB plan in 2007, which is a drop from over 114,000 in 1985 (GAO, 2009). Moreover, pension experts anticipate that plan freezes and terminations will accelerate in the future, as plan sponsors struggle to manage the increasing costs and risks (GAO, 2008). The possibility that DB plans will be eliminated from the private sector altogether exists and is growing (see Munnell, et al, 2006). This would be unfortunate, as the loss of this economic and social institution 100 years in the making would have considerable implications for the retirement security of millions of Americans. Consequently, slowing (or at least managing) the decline of private DB pensions has been a top priority for US policymakers. Any market-based or regulatory developments that have the potential to change the provision or sustainability of private DB pensions are thus of policy relevance and worth investigating.

One such development taking place in the United Kingdom has garnered the attention of US policymakers: the rise of pension fund buyouts. A pension buyout refers to a transaction in which a DB pension plan sponsor pays another company a fee to take over the assets and liabilities of the pension plan. ${ }^{1}$ Clearly, such transactions are relevant to the provision and long-term sustainability of this institution. So while the rise in pension fund buyouts has been overwhelmingly a UK phenomenon, these transactions have caught the interest of US financial services firms, plan sponsors, and policymakers. In particular, the financial services firms have shown piqued interest in importing UK style buyouts to the US.

Though US buyout activity was preemptively stymied by an IRS Revenue Ruling (2008-45) that outlawed a specific type of bulk buyout, the US policy community remains interested in buyouts for two reasons. First, in connection with the Revenue Ruling, the Treasury, Labor and Commerce Departments, in conjunction with the Pension Benefit Guaranty Corporation, issued a "Framework for Possible Legislative Change" that, if implemented, would pave the way for non-insured

\footnotetext{
${ }^{1}$ Bulk buyouts can go by various names. They are also referred to as bulk annuities, pension closeouts, group annuity contracts, pension transfers, corporate scheme adoptions, termination annuities and many other names depending on the jurisdiction and the specific nature of the buyout transaction.
} 
buyouts. So, the issue remains active. In fact, the Government Accountability Office (GAO) launched a research project on pension buyouts since the Revenue Ruling, which focused on a hypothetical non-insured buyout market in the US. In addition, this paper, which is the primary deliverable of a project funded by the Social Security Administration, focuses on lessons from the UK buyout market.

Indeed, the second reason US policymakers remain interested in pension buyouts stems from their sudden rise in popularity in the United Kingdom. From the mid-1980s to 2004, the UK market turned over around £1-2 billion per year. ${ }^{2}$ This was a very small market, as total UK DB pension liabilities are roughly $£ 1$ trillion. ${ }^{3}$ In 2008 , however, transactional volume surged to $£ 8$ billion. In addition, demand for buyouts among UK DB sponsors increased dramatically: according to a PricewaterhouseCoopers survey, 35\% of the closed DB pension plans (which represents two thirds of all UK plans) were considering a buyout of some kind in 2007 (see Timmins, 2007). To be sure, the surge in buyouts was a function of changing market variables, such as the spike in corporate bond yields used to price liabilities that allowed for cheaper transactions. But these factors cannot fully explain the meteoric rise in transactional volume. The question then is what drove this new buyout activity.

The brief answer is that UK pension buyouts underwent a two-part transformation that allowed them to evolve into a viable, and even popular, option for plan sponsors. First, the idea that buyouts were only for insolvent firms fell by the wayside. Neither the buyout providers nor the buyout purchasers today think of these transactions as restricted to insolvent firms. Because buyouts discharge plan sponsors from their pension responsibilities, they have become a way to offload a costly and risky obligation for solvent and healthy sponsors that are still committed to fulfilling their past commitments. Second, the buyout transaction has itself been the subject of experimentation and innovation. New buyout providers who entered the market in 2006 expended considerable effort to tailor their products to the specific needs of the plan sponsors. This included a series of new buyout options, ranging from the traditional fully insured buyouts that removed the entire pension plan, to partialbuyouts and 'buy-ins' of specific tranches of beneficiaries, and even non-insured buyouts by financial institutions not under the jurisdiction of insurance regulators.

\footnotetext{
${ }^{2}$ This statistic was provided during an interview by one of the oldest bulk buyout providers in the UK.

${ }^{3}$ See http://www.pensionprotectionfund.org.uk/ppf 7800 july 09.pdf.
} 
These "non-insured buyouts" actually accounted for $£ 4.5$ billion worth of volume in 2007.

The objective of this paper is to analyze more thoroughly these two transformations. While the focus is on the rise of solvent buyouts generally, the paper examines both insured and non-insured buyouts. The UK market in insured buyouts is clearly of continuing relevance for the US, given its ongoing development and popularity. Moreover, the US has a modestly active insured bulk annuity market (known as closeouts or termination annuities), so the UK experience in insured buyouts may have implications for the American bulk annuity market.

The relevance of the UK non-insured market is less obvious but still important for several reasons. First, the nominal value of non-insured actually topped insured buyouts in 2007. So the sheer size of the non-insured market in 2007 attracts attention. Second, while no non-insured transactions took place in 2008 (due to controversy associated with the 2007 transactions), the UK market remains perfectly legal and theoretically intact. These non-insured transactions may resurface in the future; to ignore them or claim they are 'dead' would be erroneous. Third, non-insured buyouts were an important step in the chronology of solvent buyouts: their brief existence was based on limitations within the insured buyout market. Therefore understanding noninsured buyouts is essential to understanding the emergence of solvent buyouts. Finally, US policymakers were particularly interested in the non-insured buyouts, since several US financial companies had been preparing to enter this market in 2008 before the Revenue Ruling took effect.

In sum, this paper achieves a deeper appreciation for solvent buyouts by comparing and contrasting the supply and demand factors underpinning both insured and non-insured buyouts. This paper thus adds to our understanding of buyouts generally and their relationship with the provision of DB pensions in the private sector more specifically. This research complements and advances the existing (albeit scarce) academic research on pension fund buyouts in the UK (see Kirkpatrick, 2007; and Blake et al., 2008 and the recent special issue in Pensions: an International Journal). More specifically, it builds on and indeed complements the US Government Accountability Office's (2009) recent paper on the potential 'risks and benefits' of a (hypothetical) non-insured buyout market in the US. As such, this paper provides insight on these transactions as a mechanism to manage DB pensions in the private sector. 
To achieve its objectives, this research adopts a multi-method approach grounded in qualitative, interview-based techniques and case studies (See Appendix for a more in depth description of methods, including the benefits and drawbacks of such an approach). Specifically, close-dialogue, which refers to interviews on a confidential basis with no-citation rights directed by a pre-determined set of questions, is used to construct a coherent narrative for the market's development as well as certain relevant corporate and transactional case studies (Clark, 1998). Rigor requires elite-level access, as only the testimony of key stakeholders and decision-makers will afford confidence in the discussion and empirical findings. Accordingly, the observations that underpin this paper's analysis were collected and cross checked during interviews with 37 individuals across 27 organizations in New York, Washington, D.C. and the greater London area. While academic practice necessitates anonymizing interviewees, these individuals are buyout providers, industry lobbyists, policymakers, regulators, consultants, actuaries, lawyers and pension executives (See Appendix for details on sampling frame). Importantly, six of the top seven UK buyout firms (based on 2008 transactional volumes) are represented, including the dominant purveyor of non-insured buyouts. The 19 individuals interviewed in the UK represent the demand for, supply of, regulation over and advice on the pension buyout market. In addition, the author interviewed 18 policymakers and DB stakeholders in Washington DC and New York to document their views on the UK buyout market. The findings in this paper are a synthesis of the input and remarks of American and British interviewees (See Appendix for details on coding and analysis of the qualitative data).

The plan for the paper is as follows. Section I provides some additional background on the UK buyout market. Section II then explains the factors driving firms to seek a buyout. Section III then offers a detailed explanation for the changing nature of the supply of buyouts. Section IV then considers the outlook for both noninsured and insured buyouts in the UK. This is followed by a discussion of the implications for the US from the UK experience in Section V. Section VI concludes. 


\section{UK Buyout Basics}

Prior to 2004, companies settled pension obligations in the UK in two ways. If solvent, the firm paid the benefits out as planned over the long term until the contracts "expired" upon the beneficiaries' deaths. The firm could also shed the pension plan by buying a bulk annuity from a regulated insurance company, which then assumed responsibility for paying all future pension obligations. A bulk annuity is, in effect, an insurance contract covering many lives instead of a single annuity covering one life. A bulk annuity can result in the dissolution of the pension fund trust, and the severance of the relationship between plan members and the sponsoring employer. This transaction is known in the UK as a bulk buyout. ${ }^{5}$

Originally, companies facing insolvency sought bulk buyouts at the behest of either a regulator or a court. A disappearing plan sponsor would use the buyout as a mechanism to ensure as much payment of the pension benefits as possible with the assets available in the plan. Given the steady trickle of plan sponsors entering bankruptcy, the market for 'insolvent buyouts' turned over roughly $£ 1-2$ billion pounds per year for the better part of two decades.

In 2004, however, the Pensions Act established the Pension Protection Fund (PPF). Based on the U.S. Pension Benefit Guaranty Corporation, the UK government designed the PPF to protect pension benefits in situations where the sponsor failed and did not have enough money in the pension scheme to fund 100 percent of benefits. ${ }^{6}$ Since insolvent firms typically have underfunded pensions, the expectation was that the PPF would eliminate much of the private, insurance-based bulk buyout market. Remarkably, the Pensions Act and the PPF actually caused an expansion in the options for settling pension liabilities for both solvent and insolvent plan sponsors.

Indeed, two new ways in which plan sponsors settle pension obligations now exist. First, the newly established PPF assumes the assets and liabilities of an underfunded pension plan involved in a corporate insolvency. ${ }^{7}$ The second and more interesting development is the increasing use of buyouts by solvent companies with

\footnotetext{
${ }^{5}$ As Craig $(2008,7)$ explains, "The term pension buyout usually refers to an insured buyout, where a trust-based occupational DB pension scheme transfers the responsibility for its pension obligations from the trust set up to administer the scheme assets to a regulated insurance company, in return for a premium payment. Following this, pensions are paid by the insurance company, rather than the trust." ${ }^{6}$ Nonetheless, as with the PBGC, the PPF does not pay $100 \%$ of benefits.

${ }^{7}$ Plans of insolvent sponsors funded above $100 \%$ are still shopped-around to insurance companies for an insured buyout
} 
healthy pension plans. ${ }^{8}$ Previously reserved for insolvent companies, buyouts now offer solvent firms the chance to offload what they perceive to be a burdensome obligation. ${ }^{9}$ As one provider said, "What applies to the distressed pension schemes and firms actually applies better to healthy plans and firms." The buyout market has thus expanded to include solvent buyouts by healthy plan sponsors. The source of market demand has therefore grown significantly, from a handful of insolvent companies with DB pensions to potentially all UK plan sponsors looking to de-risk and offload all or even just a portion of their liability to an insurance company. Rather than the buyout market disappearing after the establishment of the PPF in 2004, a buyout boom was about to take off. ${ }^{10}$ These 'solvent buyouts' underpin the resurgence in the buyout market and are thus the focus of this paper.

Within the domain of solvent buyouts, two broad categories exist in the UK: insured and non-insured. Insured buyouts work by passing all or a portion of the assets and liabilities on to an insurance company. These transactions are fairly straightforward and relatively safe: the regulations protecting pensions migrate from the Pension Regulator (tPR) to the Financial Services Authority (FSA), which provides beneficiaries with several sources of added security (see Lane, Clark and Peacock, 2009, 27). First, the FSA has strict reserve and capital solvency requirements. Second, should circumstances demand it, statutory protocols transfer pension annuity business from teetering insurance companies to healthy insurance companies so as to ensure beneficiary security. Third, if the insurance company does fail, the annuitants rank above shareholders, unsecured bondholders and creditors. Also, the Financial Services Compensation Scheme covers 100 percent of the first $£ 2,000$ and 90 percent of the remainder of an individual's claim on a failed insurance company.

From the perspective of current employees and pensioners then, insured buyouts are not very risky. Indeed, if done correctly, with all the appropriate due diligence and vetting, the insured buyout should have no detrimental effect on any stakeholders. As such, these transactions have been given a tacit endorsement by the UK government. For example, then U.K Minister for Pension Reform Mike O’Brien

\footnotetext{
${ }^{8}$ To be sure, pension funds have held annuity contracts in their pension plans for some time. However, using annuities for a complete buyout was a new phenomenon. Moreover, the widespread promotion of this strategy by insurance companies and pension consultants was also new.

${ }^{9}$ In many ways, the buyout decision is very similar to an investment decision. It is a decision about how best to apply the pension assets to ensure that liabilities are paid (Arter, 2008).

${ }^{10}$ There was considerable scope for growth, as the UK has roughly $£ 1$ trillion in pension assets.
} 
said, "A clear consensus has emerged. Insured buyouts are often very sensible and effective mechanisms for securing the pensions promise. An insured buyout can give members comfort that their benefits are backed by the safeguards provided by regulation, while providing employers with the certainty that they have met their commitments in full" (cited in Lane, Clark \& Peacock, 2008, 6).

However, certain demand- and supply-side limitations of insured buyouts led to the innovation of non-insured buyouts. In 2007, a series of large non-insured buyouts were completed in the UK. Due to their size, these new transactions received quite a lot of interest (especially from the media). In fact, the nominal value of noninsured transactions actually surpassed the level for insured buyouts that year, albeit through a few large transactions. The size of the non-insured transactions that took place engendered speculation about the market's potential impact and importance for the DB landscape in the UK (and potentially in the US). Indeed, some fundamental differences between the two types of buyouts, namely flexibility and speed, suggested to some that non-insured buyouts were potentially groundbreaking.

A non-insured buyout is a transfer of a pension plan from the original sponsor to a new sponsor (i.e. a financial institution) for fee. These transactions were done outside of the FSA regulated insurance market, which made them riskier for beneficiaries than insured buyouts. The lack of insurance however allowed for greater flexibility, since these transactions took advantage of existing pension legislation governing mergers and acquisitions in which acquired companies routinely transfer pension funds to an acquiring company without dissolving the pension trust. In these acquisitions, the pension fund remained under the purview of tPR. This afforded the buyout provider more room with the assumptions that underpin pricing, as tPR has less stringent requirements for funding liabilities. In addition, when transactions needed to be done quickly, non-insured buyouts had clear advantages over insured buyouts.

Nonetheless, non-insured buyouts were quite controversial. As Arter $(2008,28)$ notes, "...the primary risk associated with any buyout is the prospect of the buyout firm becoming insolvent and being unable to pay members' benefits in full." Since non-insured buyouts did not fall under the domain of the FSA, there was the 
perception that the risk of default was greater. ${ }^{11}$ In the end, the risks associated with non-insured buyouts proved too great for the traditionally conservative UK pension fund trustees, who, in turn attracted the attention of tPR to the transactions. This attention by tPR then drove plan sponsors back towards insured buyouts.

\section{The Demand for Solvent Buyouts in the United Kingdom}

To better understand the rise of solvent buyouts, both insured and non-insured, we must begin by investigating the origins of demand. This section tackles the demand side of the market; Section III then follows with a discussion of how supply rose to match this demand.

The decision to do a solvent buyout comes from within the sponsoring firm's management. The scheme's trustees must agree to the buyout, but they are rarely the instigators of the decision. So in order to understand the demand for solvent buyouts, we must first understand the complex relationship between plan sponsors and their pension plans. Specifically, we need an explanation for why plan sponsors are freezing, closing and ultimately offloading their DB obligations (in whole or in part) through solvent buyouts.

The motivation to offload the pension liability is derived from the complicated, uncertain and expensive nature of running a DB pension. In a simplified world, DB plan sponsors would periodically contribute money to a pension trust to ensure that sufficient assets were available in the future to cover all pension promises. These contributions would be dictated by actuaries and take into consideration all of the factors that could impact the future pension obligation. In the real world, however, this process is anything but simple. Numerous exogenous and endogenous forces routinely alter the current or anticipated value of pension assets or liabilities, resulting in unanticipated additional costs (see Box 1 for more details about these factors in the UK). The result is an unwieldy obligation that is difficult for plan sponsors to manage.

Moreover, DB pension plans are increasingly difficult to reconcile with the competitive demands placed on the modern firm. As one of the UK regulators interviewed said, "Today in the United Kingdom, finance directors are being kept awake by their pension scheme and not by their business. This is a problem." A

\footnotetext{
${ }^{11}$ In reality, the risk of insured or non-insured buyouts can only really be determined on a case-by-case basis.
} 
separate individual at a UK regulator noted, "There are a whole series of things that have jacked up the cost of providing a pension. So the sponsoring employer has this enormous liability that it didn't even know it had." The consensus is that the DB pension obligation is now simply too onerous for UK plan sponsors (see also Monk, 2008 and Jones, et al., 2008). Indeed, British interviewees repeatedly raised the issue of the competitive drag created by DB pensions.

More importantly for this discussion is that solvent buyouts are explicitly linked to the growing DB burden. The solvent buyout market, according to several interviewees, allows companies to get out from underneath their DB liabilities through a one time charge and get on with the core operations of their business. According to one buyout provider, "We give firms the wherewithal to deal with their own business by providing them with a way to honor their pension commitments while eliminating the ongoing liability and risks." ${ }^{12}$ As Blake et al. $(2008,10)$ note, "The company escapes volatility to its profit and loss account, levies to the Pension Protection Fund, and asset management fees on pension assets." Though expensive (an issue addressed later), interviewees noted the only way for the sponsor to avoid all future risks and costs of a DB plan is to do a buyout. ${ }^{13}$

However, companies have been dealing with burdensome DB pensions for the better part of two decades. The 'straw that broke the camel's back' and kicked off the growth in demand for buyouts by solvent firms was really the new accounting rules and regulations (see Box 1 in the appendix for further details). In reaction, many solvent firms decided that a buyout would be easier and less costly than compliance with the rules and regulations.

This explains why solvent firms with healthy pensions want to do buyouts. What is not clear is how firms choose the insured versus non-insured route. Given that non-insured buyouts are potentially more risky for beneficiaries, there has to be a tradeoff that makes them a compelling alternative to insured buyouts.

The most obvious reason that comes to mind is price. Indeed, a common refrain (in particular among US interviewees in favor of the UK non-insured buyout market moving across the Atlantic) was that insured buyouts are too expensive.

\footnotetext{
${ }^{12}$ It was also noted in interviews that for managers who join a firm after the plan has been closed (and thus do not participate in the plan), there is added incentive to offload the obligation.

${ }^{13}$ It was thus suggested in several interviews that firms might actually benefit from taking out a bank loan to finance the buyout, since it would result in the replacement of a difficult to quantify liability with an easily quantifiable liability.
} 
Because insurance companies are regulated by the FSA (instead of tPR) and are subject to higher reserving and solvency requirements, the cost of paying pension benefits through an insurance company is indeed higher than for a pension plan. In simple terms, if an insurer wants to take on annuities worth $£ 100$ billion, they would need to back these annuities with assets worth around $£ 108$ billion (Jones, et al., 2008). This is significantly more stringent than the funding requirements placed on a pension plan through pension regulation. As such, only a small fraction of pension plans can afford the cost of an insured buyout. By remaining under the domain of tPR, non-insured buyout prices could be much lower. This would then ostensibly make solvent buyouts available to more firms. As one non-insured buyout provider explained: "There needs to be a solution for every pension scheme." As such, the noninsured buyout was originally conceptualized as a cheaper alternative to an insured buyout.

However, while insured buyouts are expensive, it is not clear that they are prohibitively more expensive than the non-insured alternative. In fact, it is unlikely that price differences are what drove the 2007 surge in UK non-insured buyouts. The reasons for this are twofold. First, the price for insured buyouts dropped dramatically starting at the end of 2006 (for reasons discussed below), so linking price to the rise of non-insured transactions is difficult. Second, according to several pension consultants, the price for non-insured deals should not be hugely different from the insured deals. Based on the experience of interviewees, the difference in price between non-insured and insured buyouts should be around 200 to 500 basis points. This, they noted, represents the regulatory arbitrage. If a company is quoted a price much better than 500 basis points, something overly risky (or even shady) was likely going on. Also, according to interviewees, non-insured buyouts work best for a highly idiosyncratic and rare combination of a well-funded plan and a weak plan sponsor. So, while price could clearly be relevant, the types of plans that are candidates are not likely to be as constrained by price as they are by other factors. In sum, while it is true that many funds cannot afford the high price of an insured buyout, non-insured buyouts are not necessarily tools to make buyouts available to "every pension scheme."

But if price was not the basis for the upswing in non-insured buyout demand in the UK, what was? Based on interview evidence, speed appears to have been the primary demand-side driver for non-insured buyouts in the UK. The path to do a fully insured buyout is a long one (see Box 2 in the appendix for details). It can take years 
to fulfill all of the requirements to receive statutory approval from the UK government to transfer all of the assets and liabilities and dissolve the trust. ${ }^{14} \mathrm{By}$ circumventing the need for statutory approval, however, non-insured buyouts were a compelling alternative for firms that could not wait as long. In a non-insured buyout, the trust is maintained; the pension is simply transferred from one plan sponsor to another. If the data are poor (which Box 2 illustrates can be quite common), the new plan sponsor can simply charge a higher premium to take on the data risk along with the pension plan. In fact, for firms prioritizing speed, such as those looking to offload a DB pension plan quickly prior to a merger, non-insured buyouts may even be more expensive.

\section{The Changing Supply of Solvent Buyouts in the United Kingdom}

The supply side of the buyout market experienced as much upheaval in the last decade as the demand side. Predictably, the surge in demand caused the entry of more buyout providers into the market, which led to increased competition, lower prices, and later innovation in the form of non-insured buyouts.

Supply of buyouts in the early 2000s was low, in line with low demand. There were only two buyout providers: Legal \& General and Prudential. These firms were in a favorable position, as they had a duopoly over a reasonably sized market (hence the high buyout prices). But the demand was shifting from insolvent to solvent buyouts thanks to the additional burdens created by new accounting rules and the 2004 Pensions Act, and this shift did not go unnoticed by potential competitors throughout the UK insurance industry and indeed the entire financial community. With roughly $£ 1$ trillion in UK DB pension funds, a market in which all DB pension plan sponsors were potential clients was much more enticing than a market based on the handful of insolvent firms forced into buyouts (as was the case pre-2004). A commensurate rush to tap this new demand for solvent buyouts ensued, and new entrants lined up.

The first entrant occurred when a mono-line insurance company, Paternoster, was approved to write pension buyout business exclusively in 2006. With an initial capitalization of $£ 500$ million, Paternoster was the first real threat to the prevailing duopoly. Moreover, it encouraged a dramatic increase in the number of buyout

\footnotetext{
${ }^{14}$ While some interviewees thought that 6-9 months was reasonable, other interviewees noted that they had cases take as long as 3 years.
} 
providers writing this type of insurance business. Today, interviewees placed the number of firms actively interested in providing buyouts in the UK at between 12 and 15. ${ }^{15}$ (See Figure 1)

This injection of new competition has had a profound impact on the market for insured buyouts, primarily driving prices down. While insurers are highly regulated, capital requirements, based on models built by the insurer and approved by the FSA, are heterogeneous. In general, insurance companies are required to protect against 1 in 200 year events over a one-year time horizon: "However, this is not an exact science and it is to be expected that there will be a wide variety of answers for any given insurance entity" (Jones, et al., 2008, 13). Indeed, according to a UK government official familiar with buy-out models, pricing is "a bit of a black art." All in all, buyout providers have plenty of scope for competition in pricing. This flexibility allowed for a highly competitive pricing environment in 2007 and 2008.

The competition was so intense that insurance companies began undercutting each other to prevent more entrants. According to one pension consultant, some of the insurance companies were writing deals with prices that were "stupidly low." Another individual indicated that new players were "writing deals with internal rates of return in the single digits. For long-term insurance business, this is a terrible idea." The pricing was, as another interviewee put it, "mental." Why were these firms willing to write deals at these levels? On the one hand, the insurance companies were competing for market share, so they were looking to price competitors out of the market altogether.

On the other hand, there was some desperation and embarrassment among the new players because there had been a massive publicity scheme (one firm had even put their name on some London taxis), but very little was getting done in the way of transactions (vis-à-vis expectations). A number of new entrants actually wrote no new business in 2007. These firms felt pressured to get at least one deal done so as to have some credibility in the marketplace, even if these deals were underpinned by overly optimistic assumptions.

What was the affect of this competitive pricing? First of all, the effect on beneficiaries was nil, since price competition should not impact beneficiary security within the domain of insured buyouts. The FSA regulations protect beneficiaries

\footnotetext{
${ }^{15}$ This number appears set to drop, as consolidation appears increasingly likely.
} 
through capital and reserving requirements. Rather, the hyper-competitive nature of the insured buyout market in 2007 was cutting into the profits of insurance companies and using up their capital. This was a key impetus for the development of non-insured buyouts. The idea was that non-insured deals within a different regulatory environment could render solvent buyouts more profitable for the insurers.

Several non-insured deals were completed in 2007 (see Box 3 for four case studies of the non-insured buyouts). The Citigroup/Thomson deal is considered the prototypical non-insured buyout. However, it was a different insurer that set the tone and came to epitomize the non-insured buyout market in the UK: Pension Corporation, which is an umbrella organization encompassing Pension Insurance Corporation and Pension Corporation Investments (PCI). Originally, Pension Corporation was established to do insured buyouts exclusively. Yet Pension Corporation began experimenting with non-insured buyouts when competition eroded profits in the insured buyout market. Their model was simple: they looked to acquire relatively small businesses with large, well funded pension schemes. They partnered up with a private equity firm to dispose of the underlying operations of the business, leaving the management of the pension plan with PCI. Their goal was to improve the funding position of these plans, with a view to buying out the plans through a fully insured arrangement in the long-term, preferably through their sister firm Pension Insurance Corporation. PCI thus hoped to profit from both the premium it received to take over the pension plan and any remaining surplus in the pension scheme that was not needed to pay for the insured buyout in the future. ${ }^{16}$

While PCI's strategy made sense in theory, in practice non-insured buyouts proved trickier than expected. The UK trustee model makes non-insured business model difficult to implement because the trustees retain control over the pension fund and all related decision (see Thorn buyout in Box 3). Also, tPR balked at the potential risks of the non-insured deals. Indeed, the transaction Pension Corporation did with Telent ultimately put a stop to the non-insured market altogether (see Box 3 for more explanation as to why the Telent deal was so controversial).

Despite the fact that non-insured buyouts have fizzled out, the competition in the solvent buyout market remains strong. As a result, innovation continues apace. Indeed, new insured products are driving the market ahead despite the poor economic

\footnotetext{
${ }^{16}$ Note that the reversion tax in the UK is not as punitive as in the USA, making this a viable model.
} 
conditions by offering a way around the limitations that originally led to the noninsured experiments. Indeed, partial buyouts and buy-ins are very popular today. Many individuals see them as an interim step to a complete and full buyout. ${ }^{17}$ So, as is illustrated below, the outlook for solvent buyouts of the insured variety remains good over the long-term.

\section{The Outlook for Solvent Buyouts in the United Kingdom}

The years 2007 and 2008 represent the era of the solvent buyout. As described above, a series of new entrants drove the price down just as demand among plan sponsors was peaking. In addition, the prevailing economic conditions were favorable. First, the collapse in equities lagged the collapse in bonds. Second, the investmentgrade corporate bond yields used to value buyouts spiked. Basically, the scene was set for a dramatic expansion in the market at this specific time. This observation has led some to question whether the surge in activity was the product of a confluence of rare phenomena, or the beginning of an increasingly large market in solvent buyouts. In short, what is the current outlook for solvent buyouts?

\section{A) Non-Insured Buyouts}

On the non-insured side, expectations are that it will be some time (if ever) before the types of transactions Pension Corporation did in 2007 are repeated. This pessimism is due mainly to three factors. First, the economic crisis, which illustrated the fallibility of the financial sector, changed perceptions about the trustworthiness of financial institutions. Indeed, the Lehman Brothers collapse spooked those considering non-insured buyouts. ${ }^{18}$ This pushed managers and trustees farther away from non-insured deals and towards fully insured transactions. Second, Pension Corporation's business model was damaged by the fact that plan sponsors have little

\footnotetext{
${ }^{17}$ One of our interviewees noted that 'buy-ins' are separate transactions from bu-outs and should not be viewed as a type of buyout.: "The drivers for each solution can be different, with buy-in much more an investment solution whereas buy-out prompted by broader objectives (strategic, commercial, governance, administrative)." Nonetheless, many other UK consultancies do combine the two transactions. As such, for the purposes of this paper they are examined together recognizing their inherent differences.

${ }^{18}$ Lehman Brothers was actually a small player in the buyout market, actively looking for deals before they went bankrupt.
} 
control over UK pension plans. Trustees ultimately make the decisions, and their conservative nature suggests they will choose insured over non-insured every time. Finally, tPR's reaction to the Telent buyout irreparably damaged the market. By "parachuting" three independent trustees onto the board, tPR signaled to the marketplace that it did not condone these types of buyouts (see Box 3 for more details on the Telent case).

In general, tPR asks three questions when looking at transactions. First, is the covenant being severed between the employer and the pension plan? If it is, tPR needs to ensure that the members are looked after. Second, is the trustee relationship being changed in any way? If yes, tPR needs to evaluate whether this change will negatively affect member welfare. For example, if new trustees are being named, tPR verifies that no conflicts of interest exist. Finally, what is the jurisdiction of the transaction? Is it a fully insured transaction and thus an FSA regulated deal or is it a transfer falling under tPR regulations? Transactions that remain within the domain of tPR are obviously of greater interest than insured FSA transactions. As an aside, the noninsured buyouts flagged tPR's attention on all three counts. ${ }^{19}$

In sum, non-insured pension buyouts are now viewed with suspicion by nearly all stakeholder groups in the UK today. Even the pension buyout providers themselves acknowledge that non-insured buyouts are not viable in the short- to medium-term. According to one buyout provider, "Insurance is the answer; not trying to do some dodgy deal." Another buyout provider said, "This is a failed business model." 20

Although this market is currently in disrepute, non-insured buyouts are still possible: tPR's actions in 2007 discouraged non-insured buyouts, but they did not render them illegal. As such, a few buyout providers suggested that the non-insured market still offered some opportunities in the long-term. ${ }^{21}$ However, these individuals acknowledged that any transaction would require bringing together each and every stakeholder, including the various regulators and trustees, for an agreement on what is

\footnotetext{
${ }^{19}$ It did not help matters that some within tPR viewed the firms trying to do non-insured buyouts as gaming the PPF and ultimately the pension membership.

${ }^{20}$ There was also a perception among the interviewees that those firms pushing the non-insured buyouts were too aggressive. This, they suggested, is what ultimately led to tPR getting involved. In fact, one buyout provider said, "Had the people promoting these deals done a better job, it would've gotten more traction."

${ }^{21}$ In fact, according to Lane, Clark and Peacock (2009), Bridge Pointe announced in May 2009 that it would offer a non-UK insurance stepping stone that some see as another attempt at making non-insured buyouts work.
} 
best for the pension fund right from the start. In addition, some interviewees suggested that non-insured buyouts may themselves evolve into hybrid transactions that incorporate aspects of both insured and non-insured transactions (see Box 4 in the appendix for two examples of hybrid buyouts).

\section{B) Insured buyouts}

UK interviewees generally viewed the long-term prospects for insured buyouts as favorable. Specifically, the various new types of insured buyouts are now driving this market. For example, buy-ins appear to be the most popular type of buyout right now. Nonetheless, three key constraints will limit this market's growth in the short- to medium-term:

i) Underfunding. If a pension plan is underfunded, the plan sponsor has to pay out a much larger cash contribution to do the buyout. Since the recent crisis has sent many plans into a severe state of underfunding and plan sponsors can ill afford a large one time charge for a buyout at this time, this is a major constraint. So while plan sponsors may still be interested in doing a buyout, many simply cannot afford to.

ii) Capacity. Because insurers used so much of their available capital in 2007 and 2008, capacity constraints are limiting the ability of these firms to do all of today's potential transactions. According to one buyout provider, "There is not enough capital to fill demand for the insured solutions; pipelines are huge at the moment." Indeed, one of the largest buyout providers said they were turning down up to $90 \%$ of their requests for quotes. They simply do not have the capital to do all the deals that are available. In fact, the FSA has temporarily removed Paternoster's license to write new bulk annuity business due to a shortage of capital. ${ }^{22}$

iii) Volatility. The conditions in the financial sector are such that pricing deals has become very difficult; insurers are reacting by falling back on conservatism. As a result, one of the best-known buyout providers has been advising pension fund trustees to wait-out the tumultuous market before doing a buyout. Concordantly, pension plans have adopted a "wait and see" attitude on buyouts due to the deterioration in the global economy (Lane, Clark and Peacock, 2009).

\footnotetext{
${ }^{22}$ Significantly, the introduction of UK government longevity bonds could be a way of overcoming the insufficient capital in the insurance industry since this would allow some of the risk to be passed on to capital markets (see Blake, et al., 2009).
} 
In short, 2009 will see a drop-off in insured buyout activity vis-à-vis $2008 .^{23}$ (See Figure 2) However, while conditions may have deteriorated, plan sponsors are still interested in buyouts; the recent financial crisis may have actually increased corporate interest. With huge drops in asset values, the market volatility offers yet another illustration of how vulnerable plan sponsors are to exogenous shocks. Corporate finance directors are now facing the prospect that their pension plans are becoming a bigger determinant of value than the actual operations of the firm. As a result, a growing number of firms have begun the steps necessary to do a buyout. In fact, several UK pension consultants noted that most of their clients were at least preparing their data to be able to do a buyout if the opportunity presents itself. Moreover, recent evidence suggests pension freezes and closures, which are preconditions for solvent buyouts, are accelerating in the UK. ${ }^{24}$ Additionally, Lane, Clark and Peacock recently noted $(2009,14)$ that the buyout market is a "maturing and more orderly market than the initial rush in the summer and autumn of 2008." In sum, solvent buyouts of the insured variety will remain important in the UK; plan sponsors' demand appears to be too strong to think otherwise.

\section{Implications for the United States}

The UK DB pension system is different from the US DB system. For example, the power of the Pensions Regulator, the power of UK trustees and even the varying reversion tax rates are all important differences. Moreover, there are differences between the UK insurance industry and the US insurance industry, such as the weaker insurance guarantees in the US. Finally, there are clear cultural differences between the two countries, such as the rules-driven approach in the UK and the legalistic approach in the US. As such, drawing implications for the US from the UK experience is difficult.

However, US policymaker can draw some lessons from the UK. Specifically, both countries are trying to manage the decline of the DB institution in the private sector. In fact, many of the factors that drove DB's decline in the UK are also mirrored in the US (see Clark and Monk, 2007; and Munnell and Soto, 2007). For

\footnotetext{
${ }^{23}$ Indeed, a recent report by Pension Capital Strategies shows that 2009 Q1 was well off 2008 pace, even if $£ 1$ billion worth of buyouts were still transacted (Pension Capital Strategies, 2009).

${ }^{24}$ See: $\mathrm{http}: / /$ globalpensions.com/showPage.html?page=gp_display_news\&tempPageId=858526
} 
example, the "provisions of the Pension Protection Act of 2006 (PPA), which established more stringent plan funding requirements, and recent Financial Accounting Standards Board (FASB) standards, which require additional financial reporting for DB plan sponsors, place more requirements on DB plan sponsors and could possibly lead to more freezes and terminations in upcoming years" (GAO, 2009, 1). Given that the top 100 U.S. corporate pension plans saw their funded status drop by nearly 30 percentage points in $2008,{ }^{25}$ it is not surprising that one US pension lawyer noted in an interview, "Pension liabilities are too burdensome...they are eating my clients alive." So, just as in the UK, expectations in the US are that plan freezes and terminations will continue and indeed potentially accelerate (see also GAO, 2009).

Considering that DB pensions appear to be similar burdens for plan sponsors in both the UK and US, there has been speculation as to whether a US buyout market would follow the UK's upward trajectory. On the insured side of the market, the US and UK already have relatively similar experiences. A modestly active American insured bulk annuity market (known as closeouts or termination annuities) already exists, which looks very similar to the UK market before 2004. While the US market remains small, many of the UK buyout providers suggested that, over the long-term, the US insured buyout market would increase in volume. Indeed, given that the US Pension Protection Act was passed two years after the UK Pensions Act, some suggested that the insured buyout market's popularity in the US would be similarly delayed (abeit pushed back further by the recent financial crisis), but that its time would eventually come. ${ }^{26}$

On the non-insured side of the marked, there was a similar level of skepticism in the UK and US about the utility of such transactions. There was, however, a difference of opinion on how best to deal with non-insured buyouts. In the US, this took the form of a ruling that outlawed non-insured buyouts. In August 2008, the U.S. Internal Revenue Service published Revenue Ruling 2008-45, which indicated that non-insured buyouts violated the IRS's exclusive benefit rule. Thus the debate over non-insured buyouts in the US was over before a single transaction had even taken place.

\footnotetext{
25 See: http://www.pionline.com/apps/pbcs.dll/article?AID=/20090601/PRINTSUB/306019980\&nocache=1. ${ }^{26}$ However, the least risk obligation in the US creates a massive risk for US sponsors doing buyouts with insurance vehicles, which suggests to some interviewees that insured buyouts may not take off in this jurisdiction without first changing the regulation.
} 
The UK experience suggests that this was a reasonable approach. While the UK did not go so far as to make non-insured buyouts illegal, these transactions have for the most part been discredited. Moreover, UK non-insured buyouts were the product of specific circumstances driven by idiosyncratic plan and sponsor characteristics. According to a UK regulator, the type of transaction that would improve the status of all stakeholders was extremely rare (see Citigroup/Thomson buyout in Box 3). This also confirms the GAO's $(2009,26)$ recent conclusion (about a hypothetical non-insured buyout market in the US) that "...the potential advantages appear to be limited to a very narrow set of scenarios..." In sum, US policy on noninsured buyouts appears sound and is generally in line with the views of UK policymakers.

However, the decision to leave non-insured buyouts legal in the UK (though under the watchful eye of a reinforced regulator) and make them illegal in the US points towards a fundamental difference of opinion worth highlighting. In the UK, experts perceive solvent buyouts as a necessary tool for unwinding the DB pension institution from the private sector. Policymakers recognize that all types of buyouts should remain possible, even if they discourage non-insured buyouts at present. One of the UK government interviewees said, “As a society, we've moved on from defined benefit pensions... albeit recognizing that defined contribution pensions are incapable of providing similar benefits. Buyouts are part of the process of moving on." One UK regulator even said about the insured market, "If every scheme that could have done a buyout a few years ago did, we'd have less to worry about."

In contrast, US policymakers view buyouts not as the symptom of an increasingly burdensome institution, but rather as a threat to the DB institution itself. Without providing attribution, the following quotations about pension buyouts are indicative of the opinion among Washington policymakers:

- "We fight like hell to preserve every DB plan we can...is having this as an option going to push more plans to freeze?"

- $\quad$ "Do we want to encourage an exodus of the best funded pension funds?"

- $\quad$ "I'm not sure we want to give employers an easy out. How does that preserve the DB system?" 
- "Instead of allowing companies to dump their pension liabilities, we need to start asking questions about our accounting and regulations governing pension plan sponsors."

- “...We don't want to do anything that is going to make it easier for plan sponsors to dump their DB pensions."

In short, buyouts are seen in the UK as the last (or penultimate) chapter in the history of private DB pensions. As Clark (2006) says, private DB plans are facing "extinction" in the UK. The buyout is a function of this pre-existing process. ${ }^{27}$ In the US, policymakers understand that buyouts correspond with the decline of DB pensions. However, rather than seeing them as a symptom of a declining institution, they view buyouts as part of the problem. As the GAO $(2009,19)$ also noted, "Opponents to buyouts contend that... a frozen plan that remains within the firm has at least a chance of being 'thawed,' especially within a collective bargaining agreement" (GAO, 2009, 19).

\section{Conclusion}

In the UK, pension buyouts were originally for sponsors facing insolvency; the buyout was a mechanism to lock in payment of as much of the pension as possible before the firm simply disappeared. However, in 2004 the UK buyout market incurred a significant regulatory change: the 2004 Pensions Act. The newly established PPF took over from insurance companies the task of assuming pensions' assets and obligations when a sponsor failed without enough money to fund $100 \%$ of the liability. Since the majority of buyouts had been for plans funded in the 80-90\% range, the PPF could have marked the end of the private buyout market altogether. However, the UK buyout market, rather than shrinking or even disappearing, surged. Compared to the £1-2 billion in annual transactional volume that marked the pre-Pensions Act era, the UK market was $£ 8$ billion in 2008 . The objective of this paper was to explain this phenomenon, evaluate the future prospects for solvent buyouts, and draw implications (if any) for US DB pension policy.

First, this paper showed that solvent firms, driven by the added burdens created by the 2004 Pensions Act and new accounting rules in 2005, became

\footnotetext{
${ }^{27}$ Significantly, this is a phenomenon taking place globally (Munnell et al., 2008; Monk, 2009 and Dixon and Monk, 2009).
} 
increasingly interested in offloading their liability. Seeing this as a potential gold rush, new mono-line insurance companies designed exclusively for buyouts flooded the market with supply. Consequently, the price of buyouts came down dramatically, making plan sponsors all the more interested in getting rid of the liability.

Second, the paper analyzed the two sides of the solvent buyout market: insured and non-insured. By illustrating the changing nature of demand and supply through a comparison of the two types of buyouts, the paper further crystallized the role for solvent buyouts in the UK economy. While non-insured buyouts were the source of controversy, solvent buyouts of the insured variety saw their popularity spike in 2008.

The paper found the outlook for solvent buyouts to be mixed. Beyond the few transactions in 2007, the non-insured buyout market appears to be stillborn. However, the experimentation and innovation within the buyout market has continued apace, allowing for ongoing growth in insured buyouts. Indeed, phased buyouts, bulk transfers, partial-buyouts and especially buy-ins are all bespoke insured buyouts available to plan sponsors that help to circumvent the original insured limitations that led to the non-insured experiments. ${ }^{28}$ As such, while current market conditions are not favorable, the long-term prospects for insured buyouts are quite good. The increasing burden of the DB pension plan for plan sponsors seems to assure this market's ongoing vibrancy.

Those concerned about the future of private DB pensions should therefore remain interested in the pension buyout market. In a sense, the rise of solvent buyouts is a direct response to the increasingly burdensome nature of DB pensions. So while US policymakers perceive buyouts to be a threat to the sustainability of DB pensions, these transactions are perhaps better viewed as an outgrowth of this larger problem.

Simply put, DB plan sponsors in both the UK and US are increasingly struggling to reconcile competitive pressures with the provision of DB pensions. In the UK, buyouts are an option for plan sponsors to manage this burden. In the US, policymakers remain wedded to the idea that DB pensions are salvageable, which narrows their appreciation of the utility of buyouts. However, the future prospects of plan sponsors with legacy DB liabilities are today tied to the health of their pension plan: a volatile, risky and costly obligation managed by individuals external to the

\footnotetext{
${ }^{28}$ Indeed, the first ever $£ 1$ billion bulk annuity was actually a buy-in by Cable \& Wireless.
} 
firm (Monk, 2008). Viewed in this light, it is possible to see why solvent buyouts have become so popular in the UK and why US interest in such a market is on the rise. 


\section{References:}

Aberbach, J. D. and B. A. Rockman (2002). "Conducting and Coding Elite Interviews.” PS: Political Science and Politics, 35, 673-676.

Antolin, P. (2007). "Longevity Risk and Private Pensions". OECD Working papers on Insurance and Private Pensions. No. 3: doi:10.1787/261260613084.

Arter, A. (2008). "Chapter 4: Right Side of the Law: The Legal Consideration of Buyout for Trustees". Engaged Investor: Trustee Guide to Buyout".

September 12. Available online:

http://www.engagedinvestor.co.uk/Journals/Newsquest2/Engaged_Investor/Se ptember/October_2008/attachments/EI_TrusteeGuide_Chapter\%204.pdf.

Blake, D., A. Cairns and K. Dowd (2008). "The Birth of the Life Market," AsiaPacific Journal of Risk and Insurance, Volume 3, Issue 1: 6 36.

Blake, D., T. Boardman, A. Cairns and K. Dowd (2009). Everyone Wins if the UK Issues Longevity Bond. Financial Times. June 29.

Clark, G. L. (1998). "Stylized facts and close dialogue: Methodology in economic geography." Annals of the Association of American Geographers 88(1): 73-87.

Clark, G. L. (2006). “The UK Occupational Pension System in Crisis.” In Pemberton, Thane and Whiteside (eds), Britain's Pension Crisis: History and Policy. Oxford: Oxford University Press.

Clark, G. L. and R. Urwin (2008). "Best-practice pension fund governance". Journal of Asset Management. Vol. 9 (1): 2-21.

Clark G. L., Caerlewy-Smith E., Marshall J. (2006). "Pension fund trustee competence: decision making in problems relevant to investment practice". Journal of Pension Economics and Finance. 5:91-110.

Clark G. L., Caerlewy-Smith E., Marshall J. C. (2007). "The consistency of UK pension fund trustees' decision-making”. Journal of Pension Economics and Finance. 6:67-86.

Clark, G. L. and A. H. B. Monk (2007). The "crisis" in defined benefit corporate pension liabilities Parts I and II. Pensions: An International Journal 12 (1) and 12(2).

Coronado, J. et al. (2008). "Footnotes aren't enough: the impact of pension accounting on stock values". Journal of Pension Economics and Finance. 7(3): 257-276.

Craig, M. (2008). "Chapter 1: An Introduction to Pension Buyouts". Engaged Investor: Trustee Guide to Buyout". September 12. Available online: http://www.engagedinvestor.co.uk/story.asp? sectioncode $=54 \&$ storycode $=453$ $\underline{543 .}$ 
Davies, P. H. J. (2001). "Spies as Informants: Triangulation and the Interpretation of Elite Interview Data in the study of Intelligence and security services." Politics. 21(1): 73-80.

De Ferrars, M. (2009). "Getting off the hook: Buying-tout pension liabilities." Pensions: An International Journal. 14(2): 111=114.

Denzin, N. K. (1970). "The Research Act In Sociology: A Theoretical Introduction to Sociological Methods.” London: Butterworths.

Dixon A. D. and A. H. B. Monk (2009). "The Power of Finance: Accounting Harmonization's Effect on Pension Provision". Journal of Economic Geography. In press.

Feldstein, Martin (2000). “"The NBER-Sloan Project on Productivity Change”. AEA Introduction. Available online: http://www.nber.org/sloan/AEAintro.html.

GAO (2008). "Survey of Sponsors of Large Defined Benefit Pension Plans." Government Accountability Office: GAO-08-817 July.

GAO (2009). "Defined Benefit Plans: Proposed Plan Buyouts by Financial Firms Pose Potential Risks and Benefits". Government Accountability Office: GAO09-207 March

Helper, S. (2000) 'Economists and field research: "You can observe a lot just by watching." American Economic Review. 90(2):228-232.

Jones, R., M. Hunter and O. Herbert (2008). "The End Game? An analysis of the bulk buy-out market \& other de-risking solutions" Punter Southall, June 2008. Full report available online: www.puntersouthall.com/research.

Kirkpatrick, A. (2007). "Breaking the link - A consideration of the pensions buy-out market in the United Kingdom following recent developments in the accounting and regulatory regime for the measurement and reporting of liabilities of defined benefit pension schemes." Pensions: An International Journal. 12(4)" 185-197.

Lane, Clark \& Peacock (2008). "Pension Buyouts Report 2008”. Available online at www.lcp.uk.com.

Lane, Clark \& Peacock (2009). "Pension Buyouts Report 2008: Buyouts, Buy-ins and Longevity hedging". Available online at www.lcp.uk.com.

Monk, A. H. B. (2008). "The Knot of Contracts: The Corporate Geography of Legacy Costs". Economic Geography. Vol. 84 (2): 211-235.

Monk, A. (2009). "The emerging market for intellectual property: drivers, restrainers, and implications." Journal of Economic Geography. 9(4):469-491 
Munnell, et al. (2006). "Why Are Healthy Employers Freezing Their Pensions?” Issue in Brief, Center for Retirement Research. March 2006, Number 44.

Munnell, A. H. and M. Soto (2007). "Why Are Companies Freezing Their Pensions?" Center For Retirement Research Working Paper. CRR WP 2007-22.

Munnell, A. H., J. P. Aubry and D. Muldoon (2008). "The Financial Crisis and Private Defined Benefit Plans". Center For Retirement Research at Boston College Issue in Brief. Number 8-18.

Pension Capital Strategies (2009). "Buyout Market Watch: An Update Report" June. Available online: http://www.pensionstrategies.co.uk.

Pension Protection Fund (2009). "PPF 7800 Index." February. Available online: http://www.pensionprotectionfund.org.uk/ppf 7800 march 09.pdf.

Sass, S. (2006). The Development of Employer Retirement Income Plans. Oxford Handbook of Pensions and Retirement Income. G. L. Clark, A. Munnell and M. Orszag. Oxford, Oxford University Press.

Stickel, S. E. and J. J. Tucker (2007) "New Accounting Rules for Defined-Benefit Pension Plans: Impact and Fallout". Journal of Financial Service Professionals. January.

Strauss, A. L. and J. M. Corbin (1998). Basics of qualitative research : techniques and procedures for developing grounded theory. Thousand Oaks ; London, Sage.

Tansey, O. (2007). "Process Tracing and Elite Interviews: A Case for Non-probability Sampling." PS: Political Science \& Politics. 40(4): 765-772.

Timmins, N. (2007). Employers want rid of pension liabilities. Financial Times. London: Oct 19, p2.

Useem, M. (1995). Reaching Corporate Executives. Studying Elites Using Qualitative Methods. R. Hertz and J. B. Imber. London and New Delhi, Sage: 18-39.

Wood, M. (2008). "Chapter 2: Buyout Solutions: The Options Available - Case Studies That Have Worked”. Engaged Investor: Trustee Guide to Buyout”. September $12 . \quad$ Available online: http://www.engagedinvestor.co.uk/Journals/Newsquest2/Engaged_Investor/Se ptember/October_2008/attachments/EI_TrusteeGuide_Chapter\%202.pdf. 
Figure 1:

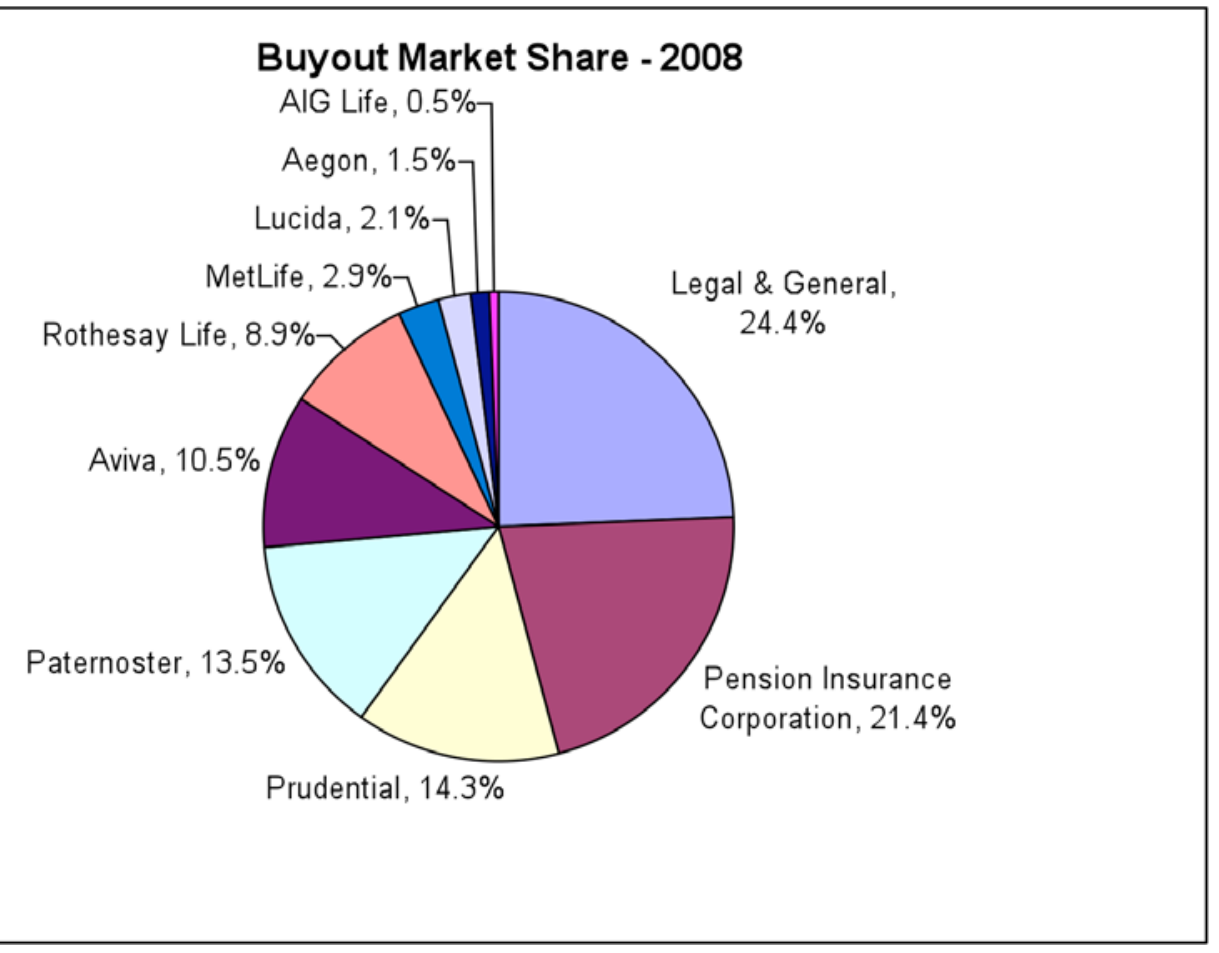

Source: Lane Clark \& Peacock (2009).

Figure 2:

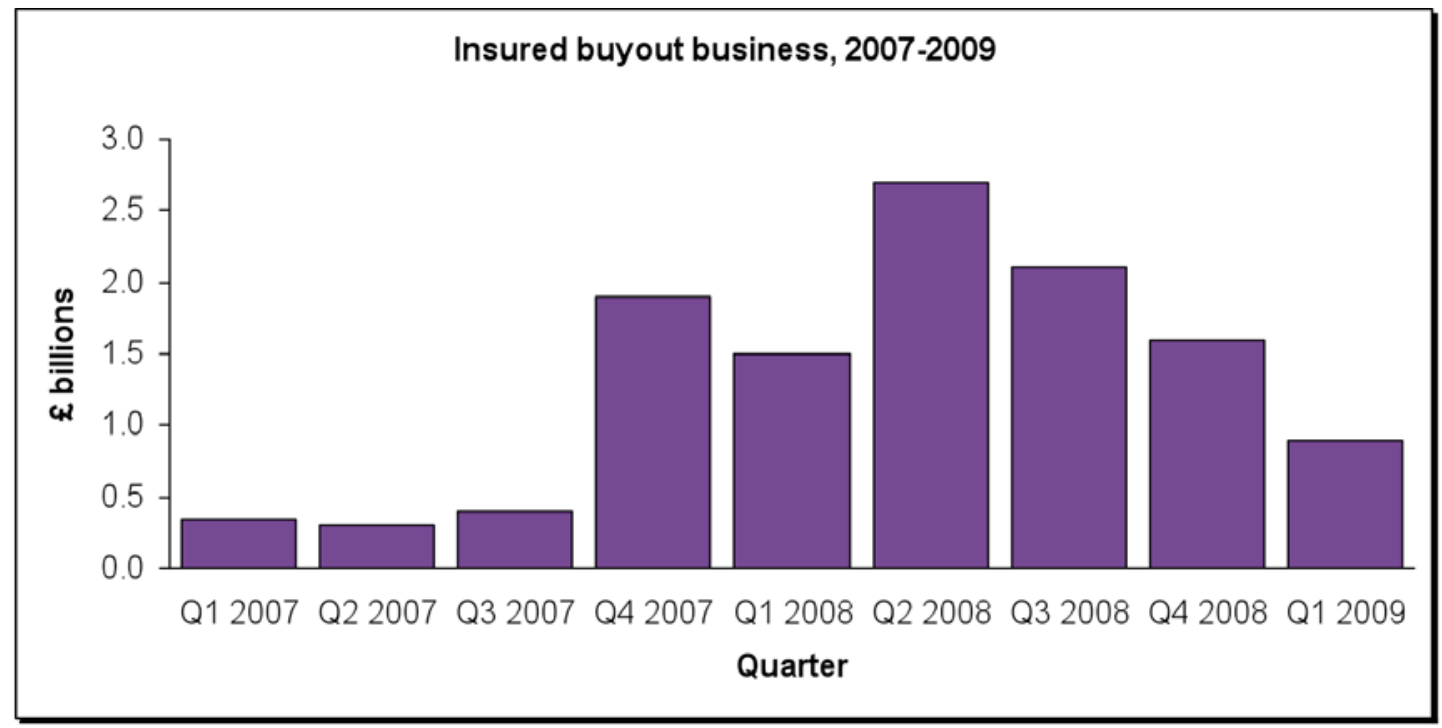

Source: Punter Southall's proprietary data. Received via personal communication. 


\section{BOX 1: The Burden of DB Pensions}

In interviews with DB stakeholders in the United Kingdom, the following five factors were cited most often as making DB pensions overly burdensome for plan sponsors:

Regulation: Since 1973, the UK has seen no less than 13 pension reforms that have changed existing legislation so as to make pension provision more costly. Whether it was through stricter funding rules, losing the dividend tax credit, adding indexation of benefits or through the creation of the Pension Protection Fund, the costs for plan sponsors over time have clearly gone up. In fact, many of our interlocutors not only saw the costs as going up, but they also suggested that the very nature of the pension liability had been unilaterally changed for firms. According to a UK government regulator, "it is simply a different promise than what it once was." While the changing regulations may have resulted in a more secure benefit for those (lucky enough) to have a DB plan, it raised costs for plan sponsors to levels that were too high. This in turn drove non-provision. As Stickel and Tucker (2007) argued, the changing pension regulations were part of a "one-two punch that will likely continue the demise of traditional defined-benefit pension plans." The other "punch' is the change to accounting rules.

Accounting: International Accounting Standards 19 (IAS 19), which came into effect in 2005, specifies how pension liabilities should be recognized on company balance sheets. In particular, it calls on firms to account for assets according to their market value, while the liabilities are discounted using a market discount rate (AA-rated corporate bond yield). IAS 19 thus injects considerable volatility into corporate balance sheets, since the reported numbers are based on current market prices. Up until this change occurred, interviewees argued finance directors could simply ignore the size of their pension deficits. With "mark-to-market" accounting, they could no longer do so. Indeed, this shift in accounting practice is seen to impact equity values of plan sponsors (Coronado et al., 2008). The impact of mark-to-market pension accounting has even been linked with non-provision of DB plans (Dixon and Monk, 2009). As one of our interviewees put it, "Mark-to-market accounting is the single biggest driver for corporate financial directors to consider doing a buyout."

Longevity: The obligation to pay a DB pension extends until the beneficiary dies. This leaves plan sponsors vulnerable to increases in longevity. If after making the pension promise, an employee lives longer than anticipated, the cost to the firm from offering this pension will increase. As such, estimates of mortality are crucial to avoid such unexpected future costs. Unfortunately, according to Antolin (2007, 6), "Past projections have consistently underestimated actual improvements in mortality rates and life expectancy." Plan sponsors have thus born additional, unexpected costs. As one company executive noted, "Nobody said the defined benefit pension system was sustainable if people were retiring for one third of their lives."

Control: The UK pension system is based on a model that places the scheme in the hands of trustees. While this is arguably a good thing, as it ensures the plan is managed in the interest of beneficiaries, it means that plan sponsors retain little influence over how the pension is managed. This lack of control is seen as a driver for pension freezes, closures and ultimately buyouts, as many finance directors are uncomfortable leaving such a large liability —oftentimes the firm's biggest liability in the hands of what one interviewee called "well-meaning amateurs." Since the 2001 
Myners Report, many have questioned the governance practices of UK pension plans. Indeed, the operations within some UK pension funds are viewed as not fit-forpurpose (Clark and Urwin, 2008). The practice of investment decision making within these trust institutions lacks, in many cases, coherence, consistency and professionalism (Clark, et al. 2006, 2007). Combining poor governance practices with the power of UK trustees reveals a dangerous situation for plan sponsors.

Competition: The above factors come together in such a way that pension plans have become considerable competitive burdens. For example, UK plan sponsors' contributions to pension plans have more than doubled in the last decade alone. ${ }^{29}$ These pension costs and risks compound other competitive constraints by siphoning off cash that could be reinvested in the core operations of the business just at the moment when the company needs it most (Monk, 2008). Indeed, the nature of pension contributions is a vicious cycle; just when a company is least able to contribute to its pension funds, such as during market turmoil and economic recession, regulations call on these firms to make additional contributions to fill underfunding. ${ }^{30}$

\footnotetext{
${ }^{29}$ See http://www.statistics.gov.uk/cci/nugget.asp?id=1278.

${ }^{30}$ Also, the aggregate funding position of UK private sector DB pension plans dropped by nearly 30 billion pounds in one month; between January and February 2009 (PPF, 2009).
} 


\section{BOX 2: The Path to Insured Buyout}

The process to do a complete buyout on an insured basis is long; it can literally take years to get all the pieces in place. It requires the following steps:

i) Before a buyout transaction can take place, both the plan sponsors and the trustees must first agree that this is the appropriate action for this plan. Once this decision has been made, the employer and trustees appoint advisers that will guide them through the buyout process. ${ }^{31}$

ii) The next hurdle for a firm interested in doing a buyout is vetting the data. This step is crucial for evaluating the liability, which is in turn a fundamental component of pricing. ${ }^{32}$ Perhaps surprisingly, most DB plans in the UK do not have all of the data on-hand to do a buyout. As such, this requires compiling data on beneficiaries' pensions, salaries, age, gender, location, and much more. This is one of the more time-consuming components of the buyout transaction.

iii) Once the data has been vetted and analyzed, the quotation process commences. Insurance companies will typically face a two stage quotation process. The initial quotation is used to weed out some insurers. The next stage is a guaranteed quotation, in which a hand-full of insurers will provide the actual price at which they would be willing to transact. After the final quotation is submitted, the finance director and trustees of the pension plan will deliberate. If a quotation is accepted, contractual negotiations are finalized and preparations for the asset transfer begin. As part of this step, the trustees will need to spend a lot of time conducting due diligence so as to determine the financial strength of the insurer (a step of considerable importance since the financial crisis began).

iv) Since all pension funds have varying characteristics, the transfer and transition of the plan's assets and obligations is typically bespoke. This will thus include considerable communication with scheme members, taking over payroll, transferring the administration of the pension, and much more.

v) In order to complete an insured buyout, the trustees and the firm must receive statutory approval. Indeed, the trustees will seek a statutory discharge from any further liability under Section 74 of the Pensions Act 1995 (see de Ferrars, 2009). In short, the government has to accept that all of the appropriate steps have been taken and that the members' benefits are secure.

\footnotetext{
${ }^{31}$ These advisers will ensure that the insurance companies being considered for the buyout are sound, that the prices being quoted are reasonable and competitive, and that the insurance company grasps the nature of the liabilities it is taking over.

${ }^{32}$ For example, the higher the average age of the participants, the less mortality risk and the lower the buyout premium charged.
} 
BOX 3: Case Studies: Non-Insured Buyouts

The non-insured buyout market was not really a market at all; it is better described as a series of anecdotal, one-off transaction. Nonetheless, these transactions are relevant to the broader discussion of buyouts as their very existence reflects problems with insured buyouts. Moreover, unlike in the US, these transactions remain perfectly legal. So, it is important to understand where they come from and what they imply. The following cases illustrate the best and worst of non-insured buyouts. While the first three transactions of 2007 appeared sound (if nonetheless trickier than expected), the fourth transaction irreparably damaged the market.

Thorn: In its first non-insured buyout, PCI assumed control of the Thorn Group in June 2007. It was acquired from Terra Firma Capital Partners in a deal that brought Thorn's $£ 1.1$ billion plan, with roughly 15 thousand former employees, over to PCI with the company. The profile of the pension plan and the sponsor fit PCI's business model perfectly. However, this transaction, which was the first one of its kind, foreshadowed the problems that would later discredit the market. Specifically, Thorn's original trustees retained control over the fund, which meant that PCI could not unilaterally impose sophisticated asset management strategies. However, this was a key part of PCI's calculus. Nonetheless, the funding position of the pension plan did improve over time. So, despite having little control, things were still more or less going according to plan.

However, as the funding position of the plan improved, the Thorn Trustees, seeing an opportunity to eliminate the remaining uncertainty for its members, decided to trade up from the non-insured buyout to a fully insured buyout. In December 2008, Pension Insurance Corporation did the insured buyout as well.

This transaction illustrated the tension between the UK trustee model and the viability of non-insured buyouts. Ultimately, trustees run UK pension plans. As such, it can be difficult to change the internal operations or influence the behavior of the plan, which was a component of PCI's business model. So when the trustees went looking to do an insured buyout, Pension Insurance Corporation was not given special treatment. To do otherwise would not have been in the interest of the beneficiaries. According to several interviewees, in order to win the business, PIC had to give up a portion of the surplus in the form of benefit increases to pensioners. This lowered the profit they made from the non-insured buyout.

Thresher: PCI acquired (also from Terra Firma Capital Partners) the wine retailer Threshers Group and its £63.1 million pension scheme, known as the First Quench Pension Scheme, in June 2007. In this deal, PCI did not make the mistake they made with Thorn. It moved quickly to appoint four new trustees to the scheme, all of whom were senior Pension Corporation partners, thereby giving more control over the operations of the pension. Concordantly, they implemented sophisticated asset liability management strategies, and the funding of the pension improved over time. Part of this improvement, however, was due to a surplus transfer of $£ 32$ million in cash from the Thresher balance sheet into an escrow account that underpinned the pension liabilities. Nonetheless, the Threshers pension continues to be sponsored by PCI and is generally seen to be doing well. Eventually, it is expected that this plan will be bought out on a fully insured basis. 
Thomson Regional Newspaper: Citigroup purchased a Thomson subsidiary so as to take over Thomson's 2200 million plan. This deal was basically an accident of corporate history: Thomson was a very weak company with a very solid pension plan; a very uncommon combination. Citigroup did not sever the trusteeship in this case. So, the transaction was not seen to marginalize the covenant, trusteeship, or the security of beneficiaries. So, according to an interviewee within a UK regulator, there was a sense that this pension plan was seeing its security increase. In other words, this was 'the model' non-insured buyout. Nonetheless, while this specific case may have been an improvement for all stakeholders, such situations were seen to be extremely rare by the regulators interviewed.

Telent: Through a special purpose vehicle, PCI acquired Telent plc, which was a subsidiary of GEC (formerly Marconi), and its $£ 3.5$ billion pension fund in November 2007. GEC established a $£ 500$ million escrow account to backstop the pension liabilities after selling its main assets to Ericsson in 2006. This made the Telent scheme very appealing for a non-insured buyout, as sophisticated management could mean that a large portion of the surplus could come back to the acquirer. (With this amount of money, however, it wasn't clear why the non-insured path was taken. Some suggested that speed, rather than price, was likely the reason.) PCI once again sought to place some of their own people on the Trustee Board. However, the existing trustees were very nervous, having reportedly been kept in the dark during the negotiations. As such, they put in a request to tPR to get involved so as to protect the interests of the plan members, which, in their opinion, were being compromised. tPR routinely tracks corporate transactions to ensure beneficiary welfare is not damaged in a merger or acquisition.

In the end, tPR took the unprecedented step of appointing three independent trustees to the Telent Pension Scheme. This put a serious damper on PCI's intentions. In fact, this specific deal was cited by many interviewees as marking the end of the non-insured buyout market in the UK. After this buyout, tPR was granted stronger powers to ensure that such transactions comply with existing laws. 


\section{BOX 4: Case Studies: Hybrid Buyouts}

Hybrid buyouts, known as 'bulk transfers,' are transactions in which “...the pension scheme's liabilities are transferred to a new pension arrangement operated by the insurer prior to being bought out [with an insured transaction]" (Jones, et al., 2008, 21). The following two transactions are representative of bulk transfers:

Emap: In November of 2007, Paternoster agreed to a full buyout of Emap's two pension schemes, the Emap Earnings Related Pension Plan and the Scottish Radio Holdings Pension Scheme, which were worth roughly $£ 170$ million. The deal needed to be done quickly, so that Emap could sell off various business operations without having to worry about the underlying pension plan. As such, it used an immediate transfer of the pension plan that was nonetheless backstopped by an insurance agreement. Emap achieved a full break with its schemes, and Paternoster took on not only the responsibility for paying the pensions but also winding-up the plan as its new sponsor. In effect, Paternoster assumed the data risk. For this transaction, Emap paid a $£ 40$ million premium to Paternoster.

Rank: In February of 2008, Rothesay Life, a subsidiary of Goldman Sachs, agreed to do a buyout with Rank. The plan had roughly 19 thousand members and was worth $£ 700$ million. All the accrued pension benefits were transferred to an insured arrangement. However, this was not a traditional buyout, as the transfer was first achieved by moving all the assets and accrued liabilities to a new pension scheme sponsored by Goldman Sachs under the proviso that the liabilities would be secured by Goldman's FSA approved insurer.

In both of the cases above, the liabilities were secured with insurance contracts. However, the plan was transferred from one sponsor to another so as to afford the original plan sponsor a bit more flexibility in the transaction. This kept the pension plan under pension regulations until such a time as the new plan sponsor could get all the pieces in place so as to meet the statutory requirements of an insured buyout. 


\section{Appendix: Details on Qualitative Methods}

As noted in the paper, this research adopts a multi-method approach grounded in qualitative, interview-based techniques and case studies. This approach is appropriate for this paper because its objective is to describe and conceptualize a new marketthat of pension buyouts - and its agents (Useem, 1995; Strauss and Corbin, 1998). Facing a dearth of quantitative data, a qualitative investigation into the characteristics of new markets is warranted. Indeed, other published work on new markets has adopted this methodology (see Monk, 2009). Notably, the GAO (2009) also adopted a similar method for its research project on the buyout market.

More specifically, the paper uses a variety of sources of information to 'map out' the current buyout market and make predictions about its future prospects. It draws data from semi-structured interviews, primary accounts of the market by insiders, corporate and regulatory filings, and secondary sources. In a sense, this method allows the researcher to operate 'from below', linking institutional and local information collected through field work with larger stylized facts and conceptual frameworks available in other sources.

It is important to acknowledge that this type of research has drawbacks. While in-situ research is an important tool for illuminating certain new or hard-to-quantify subjects, opinions and past experiences of individuals, as noted by Useem (1995), are not ideal representations of actions or facts. To address this issue, the interview findings in this paper were cross-checked with other situated accounts and empirical data through a process known as "triangulation" (Strauss and Corbin, 1998). Indeed, this research achieves rigor through the application of Denzin's (1970) notion of triangulation with respect to sources and methods. By taking a holistic approach to all of the individuals' responses, one can reach a consensus that is distanced from personal accounts and anecdotes.

As such, this paper serves to complement the standard economics research traditionally of interest to the Social Security Administration. ${ }^{33}$ While its methods may constrain strong causality claims about bulk buyouts and their impact on DB pension stakeholders, as might be done through econometric analysis, it offers unique insights into the development of this new economic space and the actors populating it. Moreover, at this stage there is no other alternative: rigorous quantitative methods are premature, as the market under consideration is too new and the required data unavailable. As Davies (2001) notes, elite interviews are crucial for research projects where there is a shortage of quantitative data.

Given the reliance on interviews, some additional explanation is required. Specifically, some information on the sampling of the target population, the coding and analysis of

\footnotetext{
${ }^{33}$ As Susan Helper (2000 p.229) noted in the American Economic Review, “...fieldwork offers a new source of inspiration, one that is complementary to more conventional [economics] methods." Martin Feldstein (2000) also argued that fieldwork and qualitative research, which are standard practice for other disciplines, should be used by more economists: “... we rarely go and look and ask. I think that is a pity. Looking and asking provide insights and suggest hypotheses -- and can shoot-down wrong ideas -- in ways that go beyond introspection and reading." (see: http://www.nber.org/sloan/AEAintro.html.)
} 
the qualitative data, and the predetermined questions that served to guide the interviews is warranted:

Sampling: As Aberbach and Rockman $(2002,673)$ have noted, "In a case study, respondents are selected on the basis of what they might know to help the investigator fill in pieces of a puzzle or confirm the proper alignment of pieces already in place." For this project, the target population that could fulfil this need was small. Therefore constructing the sampling frame was straightforward, as it included the major stakeholders involved in the buyout market, such as financial services companies who provide buyouts, policymakers and regulators, policy analysts and lobbyists, pension consultants, business executives and legal experts familiar with the buyout market in the United Kingdom and/or the United States. Specifically, I use two types of nonprobability sampling: "Purposive Sampling" and "Chain-referral Sampling" (Tansey, 2007). In the end, interviews were conducted only with those individuals that could provide expert testimony on buyouts as well as speak for the organization they represent (even if their insights were always provided on a not-for-attribution basis). ${ }^{34}$

In order to ensure that interviewees were appropriately knowledgeable, I tested each individual with a series of control questions on the specific topic for which they were being interviewed. (In some cases, however, this was unnecessary, as I was speaking directly with an individual that was widely known to be "expert".) Because interviewees were not bound to objectivity, I sought out a wide range of stakeholders to ensure that all views and opinions were accounted for; these differing opinions and views were reconciled during the coding and analysis phase of the research.

Coding: For this project, the interview data underwent three phases of coding and analysis. In the first phase, I coded and sorted the qualitative data according to topic and keyword. Next, I re-coded the data so as to flag emerging themes. In this second phase, interview evidence was cross-checked against other interviewees and sources so as to ensure reliability of conclusions. Any new conclusions or themes that emerged from interviews alone (i.e. not verifiable through other sources of information) were followed up with additional interview corroboration to confirm their inclusion in the paper (as per Davies, 2001). In the third phase, I reformulated the concepts and themes into a coherent narrative by arranging them in paper sections. Finally, once the paper was completed, I came back to certain knowledgeable interviewees for comment. These comments were then worked into the paper.

Interview Guide: I provided the following to each interviewee before our meeting. The "case study questions" subsequently served to facilitate the initial coding of interview evidence into topics:

\footnotetext{
${ }^{34}$ Where specific quotations are used to illustrate a point of view or provide insights into an organization's operations, I take pains to ensure anonymity.
} 


\title{
The Pros and Cons of Defined Benefit Pension Buyouts
}

\author{
Ashby H. B. Monk, PhD \\ Research Fellow \\ Boston College's Center for Retirement Research
}

\section{PROJECT BACKGROUND}

This project will document, analyze and conceptualize the growing market for defined benefit (DB) pension buyouts in the United Kingdom and consider its implications for the United States. The project is funded by the U.S. Social Security Administration. A key component of this research will be to assess the impacts of this market on plan sponsors, employees, retirees and government agencies. Using a series of case studies developed through an interrogation of the available literatures and close-dialogue interview methods, this project will contribute, generally, to our understanding of the future prospects for employer sponsored DB pensions and how they will contribute to retirement income. Project findings will be reported back to the Social Security Administration in the form of an academic paper and a policy briefing.

\section{AUTHOR BACKGROUND}

I hold concurrent Research Fellowships at the Center for Retirement Research at Boston College and the University of Oxford. My research, which is funded by the Leverhulme Trust (U.K.) and the Social Security Administration (U.S.), is on the design and governance of financial institutions and markets, with particular focus on pension funds. I have published numerous academic papers related to the above. In addition, I am the editor of a forthcoming book entitled Managing Financial Risk: From Global to Local (Oxford University Press), and I am the co-author of a forthcoming book entitled Sovereign Wealth Funds (Princeton University Press). I received my Doctorate in economic geography from the University of Oxford. I also hold a Master's degree in international economics from Université de Paris I Panthéon Sorbonne and a Bachelor's degree in economics from Princeton University.

\section{ETHICAL OBLIGATION}

As a member of both Boston College and Oxford University's academic communities, I am bound by a rigorous code of conduct and ethics. My purpose for requesting this meeting is purely academic. My intent is to use information collected during interviews to help conceptualize the issues under consideration and, eventually, to present these ideas in an academic paper. I will never use your name in any public document or link you to a published quotation or finding without your explicit consent. All relevant interview findings are anonymized unless otherwise requested by an interviewee.

\section{CASE STUDY QUESTIONS:}

This research is primarily focused on the following topics and sub-topics. Nevertheless, I encourage you to share all relevant information on the pension buyout market. 


\section{A) BUYOUT MARKET DRIVERS AND RESTRAINERS}

1) What is driving the pension buyout market in the United Kingdom?

i. From where does the supply come?

ii. From where does the demand come?

2) What factors are constraining this market's full development?

\section{B) BUYOUT FIRMS}

1) What types of firms perform buyouts?

2) What role do new firms play in facilitating the growth of this market?

3) How has the financial crisis affected these firms (and the market)?

4) Do you trust profit seeking companies to manage trust assets?

5) Can regulators adequately police buyout firms to ensure benefit security?

6) What happens if the buyout firms go bust?

\section{C) BUYOUT TRANSACTIONS}

1) What is the process (from start to finish) through which a plan sponsor undertakes a buyout?

i. How are pension buyouts structured and priced (in general)?

ii. How are buyouts marketed and sold to plan sponsors?

2) How are the assets and liabilities managed by the buyout firms (compared to how they were managed by the pension funds)?

\section{D) IMPACTS / IMPLICATIONS:}

1) How does the buyout affect plan sponsors?

2) How does the buyout affect current employees?

3) How does the buyout affect retirees?

4) How does the buyout affect government agencies (insurers)?

\section{E) OUTLOOK}

1) Should legislative changes be made to allow a buyout market in the U.S.?

2) What policy or regulatory measures would make you comfortable with the development of a buyout market in the U.S.?

3) Even with these changes, is it possible for the U.S. to model a buyout market after the one in the U.K., or is the U.K. market somehow unique?

4) What is your outlook for the U.K. and potential U.S. market in pension buyouts? 


\section{RECENT WORKING PAPERS FROM THE}

\section{CENTER FOR RETIREMENT RESEARCH AT BOSTON COLLEGE}

What Drives Health Care Spending? Can We Know Whether Population Aging is a 'Red Herring'?

Henry J. Aaron, September 2009

Unusual Social Security Claiming Strategies: Costs and Distributional Effects Alicia H. Munnell, Steven A. Sass, Alex Golub-Sass, and Nadia Karamcheva, August 2009

Determinants and Consequences of Moving Decisions for Older Homeowners Esteban Calvo, Kelly Haverstick, and Natalia A. Zhivan, August 2009

The Implications of Declining Retiree Health Insurance

Courtney Monk and Alicia H. Munnell, August 2009

Capital Income Taxes With Heterogeneous Discount Rates

Peter Diamond and Johannes Spinnewijn, June 2009

Are Age-62/63 Retired Worker Beneficiaries At Risk?

Eric R. Kingson and Maria T. Brown, June 2009

Taxes and Pensions

Peter Diamond, May 2009

How Much Do Households Really Lose By Claiming Social Security at Age 62? Wei Sun and Anthony Webb, April 2009

Health Care, Health Insurance, and the Relative Income of the Elderly and Nonelderly

Gary Burtless and Pavel Svaton, March 2009

Do Health Problems Reduce Consumption at Older Ages?

Barbara A. Butrica, Richard W. Johnson, and Gordon B.T. Mermin, March 2009

Financial Hardship Before and After Social Security's Early Eligibility Age

Richard W. Johnson and Gordon B.T. Mermin, March 2009

Rising Tides and Retirement: The Aggregate and Distributional Effects of Differential Wage Growth on Social Security

Melissa M. Favreault, February 2009

All working papers are available on the Center for Retirement Research website (http://www.bc.edu/crr) and can be requested bye-mail (crr@bc.edu) or phone (617-552-1762). 